\title{
Geologia das ilhas de Tamboretes, litoral norte do Estado de Santa Catarina, limite meridional do Terreno Paranaguá
}

\author{
Geology of the Tamboretes islands, northern coast of Santa Catarina State, \\ southern Paranaguá Terrain
}

\author{
MICHELANGELO TISSI BALDIN ${ }^{1}$, CARLOS EDUARDO DE MESQUITA BARROS ${ }^{1}$
}

1Universidade Federal do Paraná - UFPR, Paraná-miche_georock@yahoo.com.br, cadubarros@ufpr.br

\begin{abstract}
Resumo
As ilhas de Tamboretes se situam no litoral norte de Santa Catarina, vizinhas à llha de São Francisco do Sul, e se constituem de quatro ilhas alongadas na direção N10E-S1OW, onde afloram anfibólio-biotita sienogranitos porfiríticos de cor cinza rosado claro. A deformação dúctil heterogênea destas rochas resultou em granitos fracamente foliados, protomilonitos, milonitos e ultramilonitos. Os domínios de milonitos e de ultramilonitos têm larguras decamétrica e métrica, respectivamente. A atitude principal da foliação milonítica é N15E/80SE e sobre este plano há lineações de estiramento de atitude N05E/06, denotando a característica transcorrente da zona de cisalhamento. Os indicadores cinemáticos, representados pela foliação S/C, por porfiroclastos assimétricos de microclina e por orientações oblíquas de novos grãos em ribbons de quartzo indicam sentido sinistral. A presença de novos grãos de feldspatos permite sugerir temperaturas superiores a $450{ }^{\circ} \mathrm{C}$ durante o cisalhamento. Raramente ocorrem diques e veios aplíticos hololeucocráticos de espessura centimétrica a métrica, paralelos ou discordantes à foliação dos granitos. Os aplitos são cinza esbranquiçados, maciços ou foliados e compostos por quartzo, plagioclásio e microclina. Os granitos são cortados por dois diques de diabásio de largura decimétrica e com atitudes N15E/90 e N55W/70NE. Estes diques são, ao que tudo indica, mesozoicos e teriam sido colocados em estruturas controladas pelo arco de Ponta Grossa e pela zona de cisalhamento transcorrente. Fraturas de atitude N85W/85NE, penetrativas na escala métrica, contribuem para a formação de feições erosivas no granito que resultam em arranjos tabulares verticais proeminentes. Estes granitos possuem assinatura álcali-cálcica, fracamente peraluminosa a metaluminosa. O moderado fracionamento de elementos terras raras sugere que este magma originou-se a grandes profundidades com retenção de granada no resíduo. Os altos teores de Sr sugerem ausência de plagioclásio na fonte. As características geoquímicas destas rochas se comparam àquelas de granitos de arco magmático maduro. A geração de granitos pode ser correlacionável à colisão neoproterozoica-eo-paleozóica do Terreno Paranaguá com a Microplaca Luís Alves.
\end{abstract}

Palavras-chave: Ilhas de Tamboretes; Milonitos; Sienogranitos, Terreno Paranaguá.

\begin{abstract}
Tamboretes islands are located in the northern coast of Santa Catarina State, southern Brazil. On the four N1OE-S1OW elongated islands there can be described porphyritic amphibole-biotite syenogranites. These rocks were deformed in decameter-wide ductile shear zone generating weakly foliated rocks, protomylonites, mylonites and ultramylonites. On the N15E/80SE mylonite foliation one can observe stretching lineation N05E/06. S/C foliation, asymmetric K-feldspar porphyroclasts and oblique foliation in quartz ribbons indicate sinistral sense to the mylonite zone. The presence of new feldspar grains suggests that the shear developed under temperatures higher than $450^{\circ} \mathrm{C}$. Scarce aplitic veins and dikes are parallel to the foliation observed in the host granites. Two diabase dikes crosscut the granites (N55W/70NE and N15E/85SE), following in one hand the orientation of the Ponta Grossa arc, and in the other hand the N5E strike-slip zone. Conspicuous N85W/85NE fractures favored erosive features marked by metric vertical tabular blocks of granites. These granites display alkali-calcic and weakly peraluminous to metaluminous signature. Their rare-earth elements patterns, outlined by moderate fractioning, could suggest deep source of magmas and the presence of garnet in the residuum. High $\mathrm{Sr}$ values could indicate the absence of plagioclase in the source. The geochemical signature of these granites is comparable to that of the mature magmatic arc granites, which origin would have been related to the Neoproteorozoic-Early Paleozoic collision of the Paranaguá terrane with the Luís Alves microplate.
\end{abstract}

Keywords: Tamboretes Islands; Mylonites; Syenogranites; Paranaguá Terrane 


\section{Introdução}

As ilhas de Tamboretes, no litoral norte do Estado de Santa Catarina, adjacentes ao município de São Francisco do Sul, localizam-se entre dois domínios geotectônicos distintos: a Microplaca Luís Alves e o Terreno Paranaguá, estudados por diversos autores (Hasui et al. 1975, Hartmann 1976, 1979, Kaul 1979, 1980, Kaul et al. 1982, Silva 1984, 1987, Basei 1985, Basei et al. 1987, Mantovani et al. 1989, Basei et al. 1990, 1992, Siga Junior et al. 1990, Siga Junior et al. 1993, Siga Junior 1995). Estudos mais recentes (Cury 2009) permitiram o avanço considerável sobre 0 entendimento da geologia do Terreno Paranaguá. Entretanto, sua articulação com a Microplaca Luís Alves e questões sobre a conexão entre as placas merecem ser abordadas com novos dados geológicos.

As rochas que formam as ilhas de Tamboretes, embora analisadas anteriormente por diferentes autores em mapas e folhas geológicas (DNPM 1986, IBGE 2004, Iglesias et al. 2011), ainda não haviam sido estudadas detalhadamente em termos petrográficos, estruturais e geoquímicos.

Neste contexto, os problemas de ordem cartográfica e geotectônica do limite sul do Terreno Paranaguá estimularam a realização da análise minuciosa das rochas das ilhas de Tamboretes (São Francisco do Sul) e das ilhas dos Remédios e Feia (Balneário Barra do Sul). Neste trabalho será apresentada a geologia das ilhas de Tamboretes.

A área de estudo localiza-se no sul do Brasil, no nordeste estado de Santa Catarina, no Arquipélago de Tamboretes, próximo ao município de São Francisco do Sul (2614'36"S/4838'17"W) (Figura 1). O acesso às ilhas de Tamboretes é realizado por barco a partir do Balneário Barra do Sul.

As ilhas de Tamboretes estão localizadas numa área geológica de interesse relevante pois encontram-se na justaposição de dois domínios tectônicos: a Microplaca Luís Alves e - Terreno Paranaguá. Outras pontos que motivam este estudo são a posição estratigráfica controversa das rochas das ilhas de Tamboretes bem como a excelente qualidade dos afloramentos, os quais permitem acompanhar de modo contínuo as feições estruturais. Este trabalho visa caracterizar os aspectos estruturais, petrográficos e geoquímicos das rochas das ilhas de Tamboretes, a fim de compreender a origem dos magmas que geraram àquelas rochas, bem como o seu ambiente geotectônico. Os dados obtidos contribuíram para o posicionamento estratigráfico daquelas rochas.

\section{Geologia regional}

Trabalhos anteriores situados na região meridional do Cinturão Ribeira e norte do Cinturão Dom Feliciano identificaram três compartimentos geotectônicos principais: Microplaca Luís Alves, Microplaca Curitiba e Terreno Paranaguá (Figura 1B).

\subsection{Microplaca Luís Alves}

A Microplaca Luís Alves (Figura 1B) se estende por $6.000 \mathrm{~km} 2$ e tem espessura de crosta de 45 km (Basei et al. 1998). Está localizada no nordeste de Santa Catarina e sudeste do Estado do Paraná (Figueiredo et al. 1997).

Segundo Basei et al. (1992), a Microplaca Luís Alves tem forma retangular e compreende ortognaisses caracterizados pela alternância de bandas quartzo-feldspáticas com bandas de minerais máficos. Afloram adicionalmente, migmatitos de ocorrência limitada, além de granitos, rochas ultramáficas, gnaisses calciossilicáticos, kinzigitos, formações ferríferas e lentes de quartzitos.

Os gnaisses granulíticos têm bandamento de direção NW e superfície de transposição, muitas vezes paralela ao bandamento. A superfície de transposição apresenta-se dobrada com atitudes do plano axial preferencialmente para NW-SE e eixos de dobras com orientação predominante para $\mathrm{S} 30-50 \mathrm{E} / 400-60$, N20-60W/40-80. As dobras são suaves e abertas (Basei et al. 1992). De acordo com Figueiredo et al. (1991), os gnaisses granulíticos são cálcio-alcalinos. 

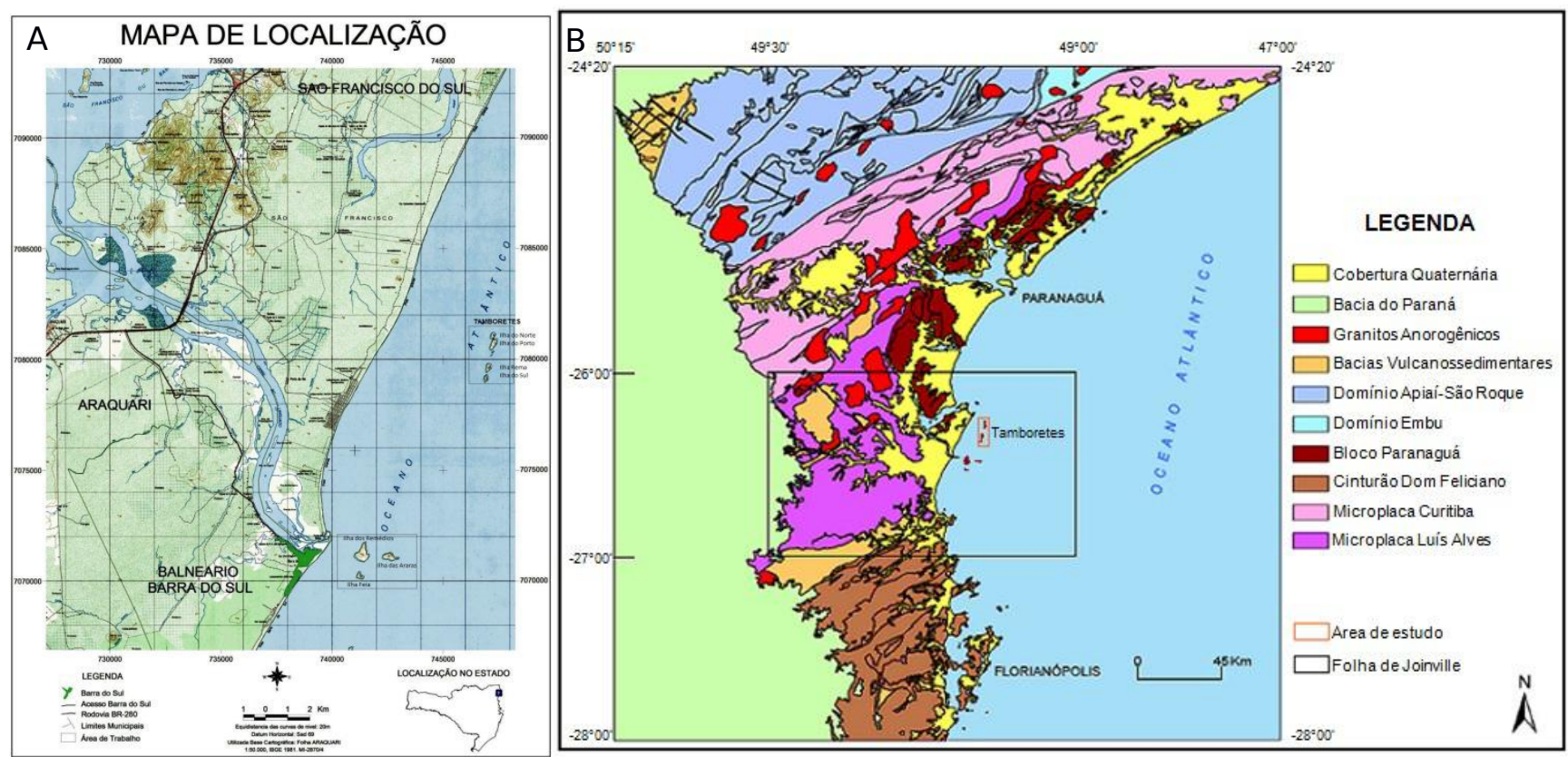

Figura 1 - A) Localização da área de estudo (Fonte: Folha Topográfica de Araquari; SG-22-Z-B-II-4/MI-2870-4), IBGE (1981). B) Mapa tectônico simplificado do leste catarinense, destacando as ilhas estudadas (Adaptado de: Carta Geológica SG. 22-Z-B; Folha Joinville - Iglesias et al. 2011).

Datações Rb-Sr em rocha total (Siga Junior et al. 1993, Siga Junior 1995, Sato et al. 2003) fornecerem idades em torno de $2,7-2,5 \mathrm{Ga}$ (Arqueano) e 2,2 - 1,8 Ga (Paleoproterozoico). Datações K-Ar em biotita, anfibólio e plagioclásio resultaram em idades entre 2100-1700 Ma (Siga Junior et al. 1993). De acordo com Hartmann et al. (2000), os protolitos foram submetidos à quatro fases metamórficas. A fase M1 de fácies granulito teria ocorrido em $2675 \pm 12$ (fácies granulito) e a fase M2 de fácies anfibolito seria paleoproterozoica (2,1 Ga). A fase M3 de fácies granulito teria ocorrido em $2168 \pm 18$ $\mathrm{Ma}$. Na fase M4 teria se formado clorita e epidoto em zonas de cisalhamento.

\subsection{Microplaca Curitiba}

A Microplaca Curitiba limita-se no setor noroeste com o Domínio Apiaí através da Zona de Cisalhamento Lancinha (Basei et al. 1998) e a sudeste com os gnaisses granulíticos da Microplaca Luís Alves balizado pela Zona de Cisalhamento Piên-Tijucas (Siga Junior 1995), além do arco magmático representado por granitos cálcio-alcalinos deformados (Suíte Granítica Rio Piên) de idade neoproterozoica (Machiavelli et al. 1993) (Figura 1B).
A Microplaca Curitiba é constituída por gnaisses-migmatíticos bandados e gnaisses graníticos bandados, leucogranitos foliados e biotita gnaisses lepidoblásticos com frequentes intercalações de corpos anfibolíticos e de xistos magnesianos (Complexo Atuba), tendo como cobertura as sequências metassedimentares Capiru, Setuva e Turvo-Cajati.

As estruturas dos gnaisses-migmatíticos têm orientação geral NE-SW, marcadas pela presença de "augens" de feldspato e quartzo (Basei et al. 1992, Siga Junior et al. 1994, Siga Junior 1995). Critérios cinemáticos indicaram transporte tectônico para sul-sudeste.

Segundo Siga Junior (1995), as datações $\mathrm{U}-\mathrm{Pb}$ em zircão revelaram idades do Complexo Atuba em torno de 2,0 Ga e com evento de migmatização em $600 \mathrm{Ma}$. Siga Junior et al. (2007) obtiveram no Complexo Atuba idades arqueanas (3200 a $2650 \quad \mathrm{Ma})$, paleoproterozoicas ( 2100 Ma e $2400 \mathrm{Ma})$ e neoproterozoicas (620-600 Ma). Para Harara (2001) a Suíte Rio Piên-Mandirituba tem idades de 620 a 610 Ma (período pré-colisional) e idades de 605 a $595 \mathrm{Ma}$ (período tardi-colisional). 


\subsection{Terreno Paranaguá}

O Terreno Paranaguá compreende as porções orientais do Paraná, nordeste de Santa Catarina e sudeste de São Paulo (Figura 1B). Os limites a norte e a oeste são definidos pela Microplaca Luís Alves por falhas de cavalgamento, a sul e a sudoeste pelas zonas de cisalhamento Palmital, Alexandra e Garuva, a leste pela linha de costa, e a noroeste pela Microplaca Curitiba (Cury 2009). No Terreno Paranaguá há rochas distribuídas em uma faixa de direção NE-SW, com cerca de $250 \mathrm{~km}$ de extensão e $30 \mathrm{~km}$ de largura. Segundo Cury (op. cit.) no Terreno Paranaguá se destaca um complexo ígneo polifásico representado pelas suítes Morro Inglês, Rio do Poço e Canavieiras-Estrela.

O Granito Morro Inglês (Lopes 1987) é cinza claro, leucocrático, maciço e foliado, tem granulação média a grossa e foliação incipiente. Também há enclaves dioríticos de granulação fina, com formas variadas e dimensões centimétricas. Feições migmatíticas são comuns nestas rochas. Estes granitoides são cálcio-alcalinos de alto $\mathrm{K}$ a shoshoníticos, e têm teores altos de $\mathrm{Ba}, \mathrm{Nb}, \mathrm{Zr}$, $\mathrm{Rb}, \mathrm{Sr}$, Th e K2O (Cury 2009).

O Granito Rio do Poço (Lopes 1987) engloba sienogranitos e leucogranitos com duas micas, de granulação média e foliados localmente. Os sienogranitos são metaluminosos a peraluminosos e são comparáveis aos granitos do tipo A. Os leucogranitos com duas micas são peraluminosos, com termos mais empobrecidos em elementos terras raras (ETR) pesados (Cury 2009).

A Suíte Canavieiras-Estrela engloba monzogranitos, quartzo-monzodioritos e leuco-granodioritos inequigranulares e com porções porfiríticas. Seus teores de K2O e de $\mathrm{Na} 2 \mathrm{O}$ são, respectivamente, menores e maiores do que aqueles da Suíte Morro Inglês. As duas suítes mostram variações de $\mathrm{Sr}$ e $\mathrm{Ba}$, altos teores de $\mathrm{Zr}$ e $\mathrm{Rb}$ e médios a altos teores de $\mathrm{Y}$ e Nb (Cury 2009).

Segundo Cury (2009), as idades das suítes Morro Inglês, Rio do Poço e Canavieiras-Estrela variam de 600 a $580 \mathrm{Ma}$ e marcam o principal período do magmatismo no Terreno Paranaguá. Também foram encontradas idades mais antigas (620-610 Ma) com menor frequência, evidenciando um episódio magmático precoce.

\section{Geologia das ilhas de Tamboretes}

As ilhas de Tamboretes, localizadas nas proximidades do município de São Francisco do Sul, são formadas pelas ilhas do Norte, do Porto, Rema e do Sul, as quais têm forma alongada e estão orientadas na direção NNE-SSW (Figuras 1B, 2 e 3).

Nas ilhas de Tamboretes predominam granitos porfiríticos pouco deformados e foliados, granitos protomiloníticos, granitos miloníticos e granitos ultramiloníticos, de acordo com a classificação de Sibson (1977). Diques e veios aplíticos foram observados na parte oeste da ilha Rema. Na região sul da Ilha do Norte aflora dois diques de diabásio com orientações N55W e N15E.

\subsection{Petrografia e Estrutura dos Granitos}

Os granitos das ilhas de Tamboretes têm cor rosada clara, granulação grossa, textura porfirítica, composição sienogranítica e biotita como o mineral ferromagnesiano. Os sienogranitos foram deformados por uma zona de cisalhamento dúctil de atitude N15E/88SE. A variação na intensidade da deformação dúctil é traduzida pela presença de granitos fracamente foliados (Figura 4A), protomilonitos (Figura 4B), milonitos (Figura 4C) e ultramilonitos (Figura 4D).

A foliação milonítica é definida pela orientação preferencial de cristais de quartzo e feldspatos, os quais formam níveis de cristais finos. Estes níveis possuem aspecto anastomosado, lenticular e descontínuo, quando contornam porfiroclastos centimétricos de microclina. Localmente pode-se verificar, sobre o plano da foliação $\mathrm{S} n+1$, lineação de estiramento mineral de atitude N06E/6 em granitos protomiloníticos e em granitos ultramiloníticos. Estas estruturas são marcadas pelo estiramento de quartzo e feldspato. Diques e veios aplíticos ocorrem localmente.

Na porção oeste e sul da ilha do Norte e na região oeste da ilha do Sul afloram granitos porfiríticos fracamente foliados ao longo de domínios de direção NE. Estas rochas mostram textura fanerítica inequigranular porfirítica, cor cinza claro a médio e são compostas por microclina (50\%), quartzo (35\%), plagioclásio (10\%) e biotita (5\%). Fenocristais subédricos de microclina de 
tamanho variando entre 0,5 a $2,5 \mathrm{~cm}$ exibem fraca a incipiente orientação preferencial. Os cristais da matriz são médios, subédricos a anédricos. O índice de cor é leucocrático. Geralmente a estrutura é foliada, definida pela orientação preferencial incipiente a moderada de biotita e microclina. Fraturas com espaçamento métrico são relativamente comuns nestas rochas. Os cristais de opacos primários (2\%) são equigranulares finos, anédricos a subédricos e apresentam forte orientação preferencial em níveis junto com a biotita.

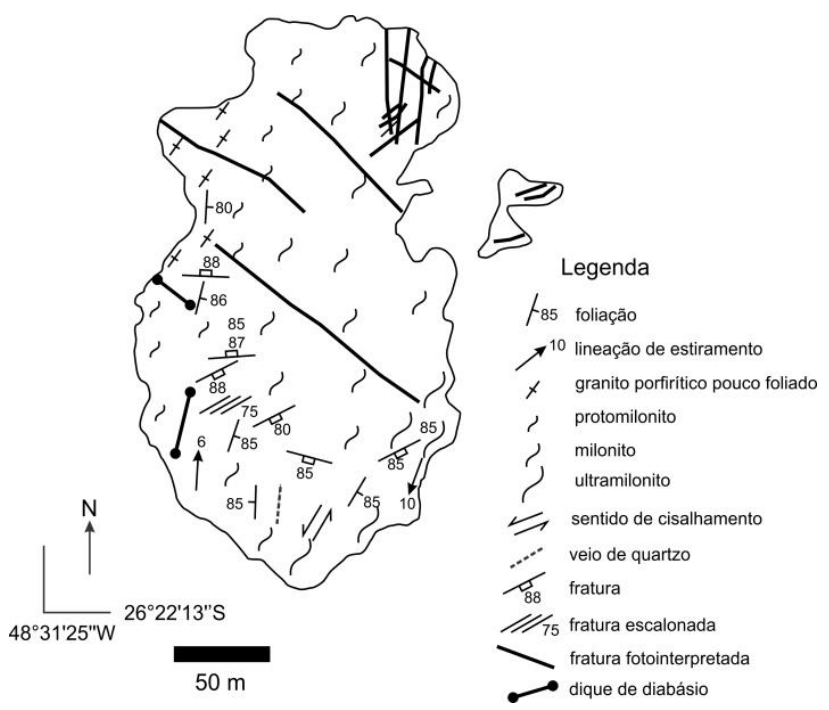

Figura 2 - Mapa geológico simplificado da ilha do Norte (Tamboretes).

Entre os acessórios ocorrem allanita, titanita, zircão, apatita, granada e turmalina. Os minerais de alteração são opacos secundários, epidoto e carbonato.

No oeste da ilha do Norte afloram granitos protomiloníticos de cor cinza claro e granulação média a grossa. Os cristais de biotita e anfibólio se dispõem em níveis anastomosados. A textura milonítica é caracterizada por porfiroclastos de microclina em meio à matriz recristalizada. A foliação é definida pela forte orientação preferencial de cristais de microclina, biotita e pelos cristais alongados de quartzo.

Os cristais de microclina (40\%) são inequigranulares finos a grossos, anédricos a subédricos, e mostram forte orientação preferencial. Os porfiroclastos são subédricos a anédricos, médios a grossos (1 a $2 \mathrm{~cm}$ ), fraca a moderadamete orientados. Suas bordas foram parcialmente recristalizadas para novos grãos finos, há extinção ondulante, pertitas em chama e microfalhas. Mirmequitas ocorrem de modo localizado.

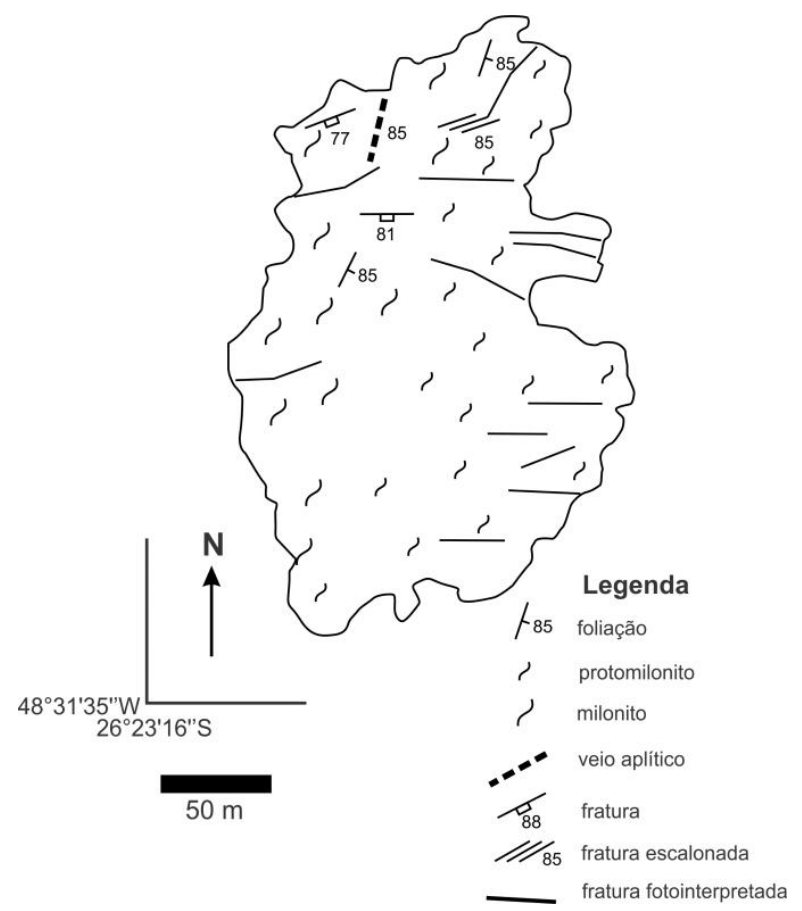

Figura 3 - Mapa Geológico da ilha do Sul (Tamboretes).

Os cristais de quartzo (20\%) são inequigranulares finos a médios, anédricos, mostram extinção ondulante, lamelas de deformação, forte orientação preferencial e formam agregados alongados de subgrãos e novos grãos. Estes agregados contornam porfiroclastos de oligoclásio e microclina (Figura 5A). 

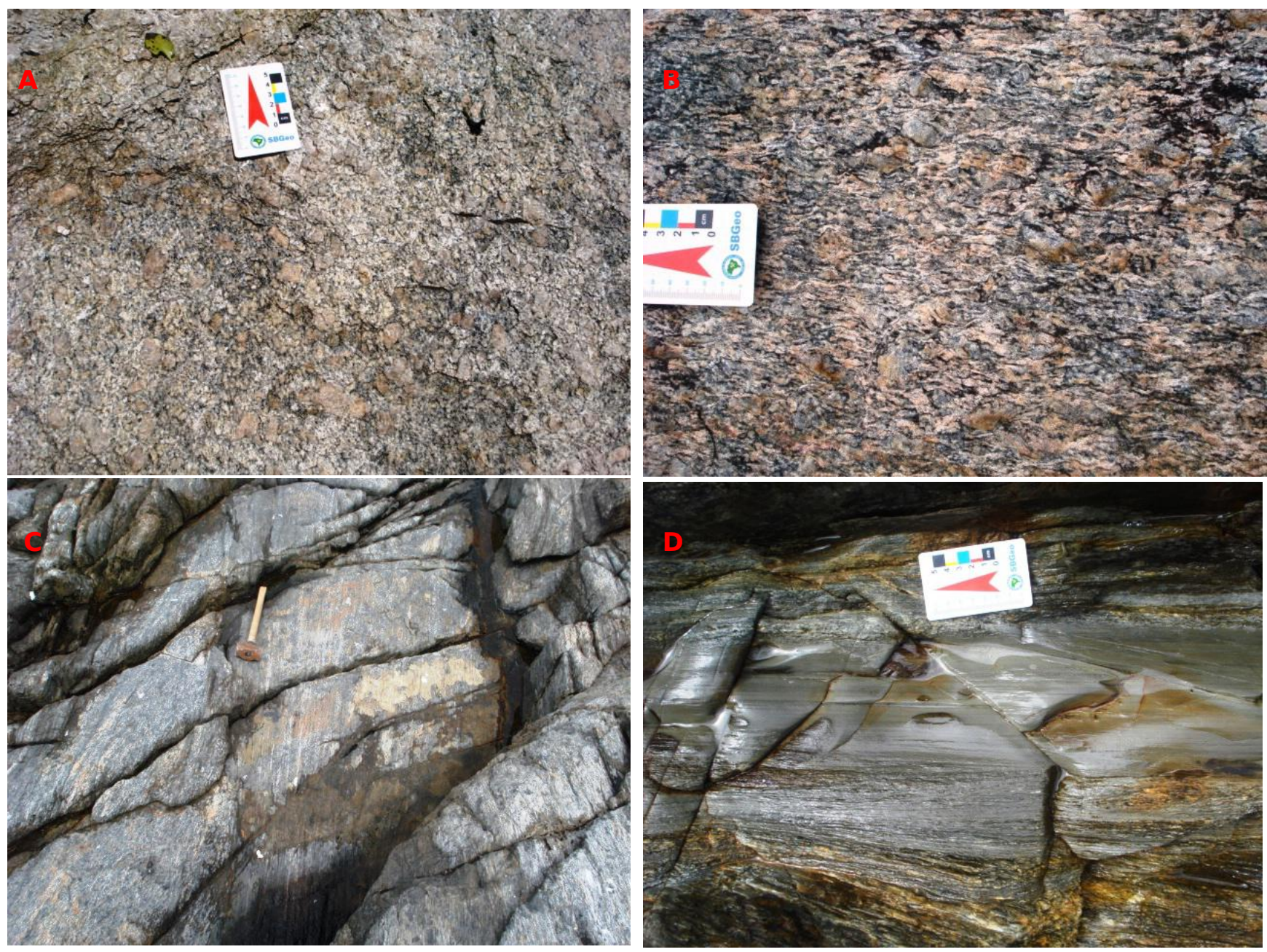

Figura 4 - A) Granito porfirítico da porção oeste da llha do Norte com foliação marcada pela orientação preferencial de biotita e microclina. B) Granito protomilonítico com porfiroclastos de microclina e foliação anastomosada; C) Granito com foliação milonítica marcada por níveis ricos em biotita que contornam porfiroclastos alinhados de microclina; D) Ultramilonito granito com espessura da ordem de $50 \mathrm{~cm}$.

Os cristais de oligoclásio (20\%) são inequigranulares finos a médios, anédricos a subédricos prismáticos, e ocorrem principalmente sob a forma de porfiroclastos com forte orientação preferencial. Apresentam encurvamento da geminação, extinção ondulante, kink bands, bandas de deformação e microfalhas. Microfraturas são preenchidas por quartzo. Subgrãos ocorrem localmente. A saussuritização é moderada a forte, sobretudo nos núcleos dos cristais.

Os cristais de biotita (15\%) são inequigranulares finos a médios, anédricos a subédricos e mostram moderada orientação preferencial. Encontram-se associados com hornblenda em níveis contínuos ou anastomosados, contornando porfiroclastos de feldspatos, os quais exibem extinção ondulante, microfraturas e kink bands. A biotita está moderadamente alterada para opacos e clorita.

A hornblenda (5\%) é equigranular fina, anédrica a subédrica, possui orientação preferencial moderada a forte, e geralmente se associa à biotita e titanita formando níveis anastomosados. Pode mostrar microfraturas e extinção ondulante.

Os granitos miloníticos predominam nas ilhas de Tamboretes (Figura 4C), têm cor cinza claro a escuro, matriz fina e porfiroclastos de microclina com até $2,5 \mathrm{~cm}$. A biotita mostra forte orientação preferencial e se dispõe em níveis preferenciais algo anastomosados e 
alternados com níveis quartzo-feldspáticos, o que define a forte foliação $S n+1$ milonítica.
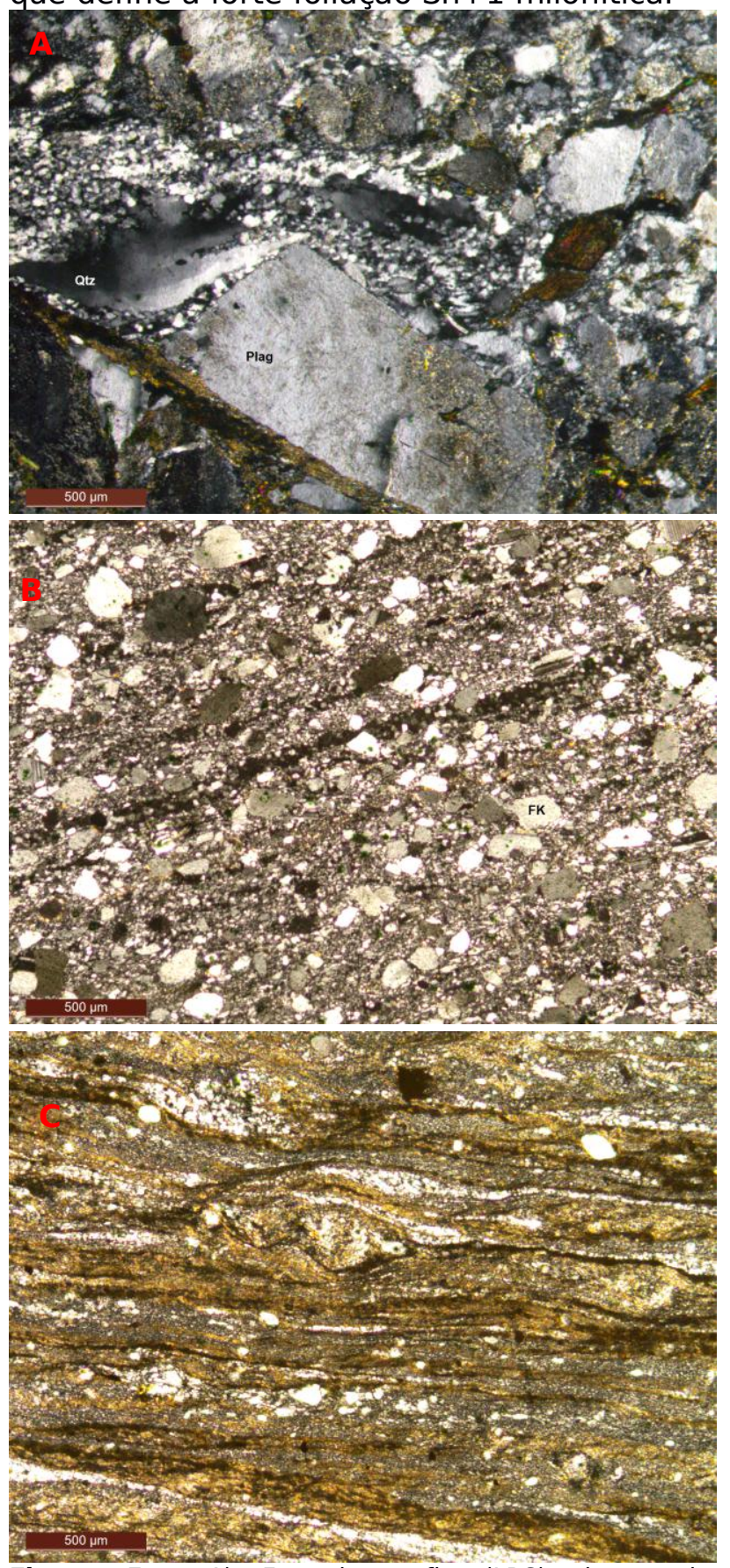

Figura 5 - A) Fotomicrografia (LPC) do granito protomilonítico: cristais de quartzo orientados contornando porfiroclastos de oligoclásio com subgrãos e circundados por novos grãos. B) Fotomicrografia (LPC) do granito milonítico: cristais de microclínio com boa orientação preferencial. C) Fotomicrografia (LPP) do granito ultramilonítico: cristais de granulação muito fina orientados segundo a direção da foliação milonítica (Qtz: quartzo; Plag: plagioclásio; Fk: microclínio).
Os cristais de microclina (35\%) são inequigranulares finos a grossos, subédricos, pertíticos e possuem forte orientação preferencial (Figura 5B). Ocorrem feições do tipo augen e sigmoides. Porfiroclastos têm novos grãos muito finos nas bordas, extinção ondulante, subgrãos, microfraturas e microfalhas.

Os cristais de quartzo (25\%) são inequigranulares finos, anédricos, exibem extinção ondulante moderada e novos grãos formam agregados alongados e fortemente orientados ao longo da foliação milonítica. Apresentam-se também em níveis descontínuos e intercalados com níveis ricos em biotita. Subgrãos formam agregados e podem mostrar disposição oblíqua.

Os cristais de oligoclásio (20\%) são inequigranulares finos a grossos, subédricos prismáticos a localmente anédricos e mostram forte orientação preferencial. Porfiroclastos exibem formas ocelares, subgrãos, encurvamento da macla, extinção ondulante, kink bands e microfalhas. Nas margens dos porfiroclastos são observados novos grãos de granulação muito fina.

Granitos ultramiloníticos ocorrem no sudeste da ilha do Norte em domínios de 15 $\mathrm{cm}$ a $2 \mathrm{~m}$ de espessura (Figura 4D). Caracterizam-se pela redução acentuada no tamanho dos feldspatos, cujos cristais novos grãos circundam porfiroclastos (Figura 5C). A foliação é anastomosada, bem pronunciada, e sua natureza é dúctil. Estas rochas têm cor cinza escuro, granulação muito fina e raros porfiroclastos de microclina. São constituídos pela alternância submilimétrica a milimétrica de níveis quartzo-feldspáticos e de níveis ricos em biotita e opacos.

O quartzo ocorre como cristais inequigranulares muito finos a finos, anédricos e estirados. Podem mostrar extinção ondulante e forma sigmoidal ou apresentar agregados de subgrãos e novos grãos orientados segundo a foliação ultramilonítica.

Os cristais de microclina e plagioclásio são inequigranulares finos, anédricos a subédricos, pertíticos e orientados segundo a foliação ultramilonítica com algumas evidências de rotação. Ocorrem novos grãos, extinção ondulante e estiramento como feições de 
deformação. Porfiroclastos possuem microfalhas oblíquas à foliação.

Os cristais de biotita são finos, subédricos e mostram boa orientação preferencial ao longo da foliação ultramilonítica.

Os opacos primários se associam à biotita, são equigranulares finos, subédricos e apresentam moderada orientação preferencial. Os opacos secundários são inequigranulares muito finos a finos, anédricos, apresentam fraca orientação preferencial e são interpretados como produtos da alteração da biotita.
Os cristais de titanita secundária são inequigranulares muito finos a finos, anédricos e formam agregados com pouca orientação preferencial.

Os indicadores cinemáticos são representados por porfiroclastos sigmoidais (Figura 6A), foliação oblíqua em agregados de subgrãos/novos grãos de quartzo (Figura 6B) e microfalhas sintéticas em porfiroclastos de feldspatos (Figuras 6C e 6D). A utilização destes critérios permitiu estabelecer o sentido sinistral para o cisalhamento transcorrente.

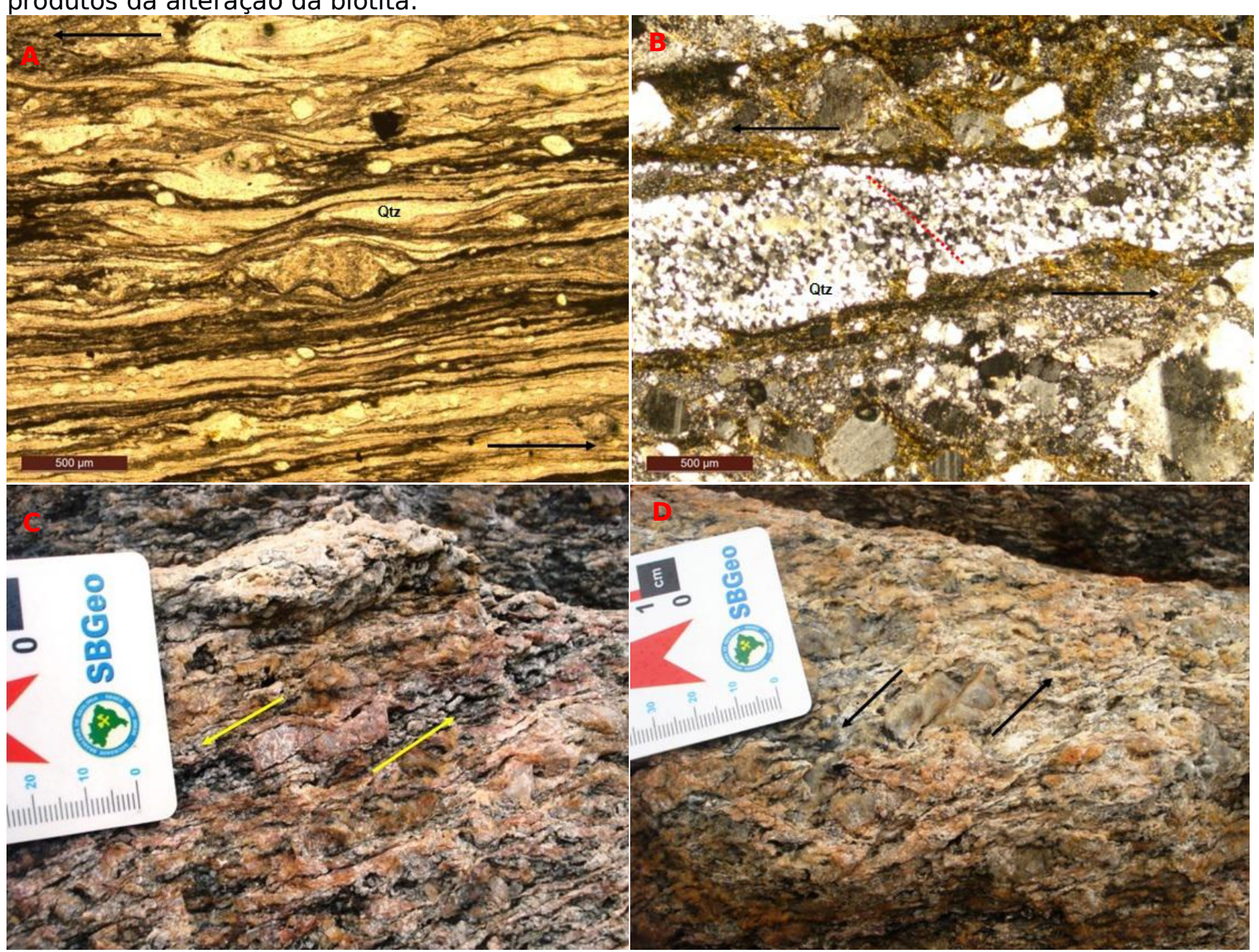

Figura 6 - Indicadores cinemáticos sugerindo movimentação sinistral para a foliação Sn+1. A) Fotomicrografia (LPC) do granito ultramilonítico da ilha do Norte: feições sigmoidais de quartzo; B) Fotomicrografia (LPC) do granito milonítico da ilha do Norte: clivagem oblíqua formada por novos grãos de quartzo. C e D) Porfiroclasto de microclina com falha sintética sinistral.

Pouco frequente nas ilhas de Tamboretes, os diques e veios aplíticos são tabulares, têm espessura centimétrica a métrica e são paralelos (N15E/65SE) ou discordantes à foliação das rochas hospedeiras. Os diques podem ser numerosos e contínuos em extensão. No oeste da Ilha Rema há um dique 
aplítico com $70 \mathrm{~cm}$ de espessura (Figura 7), cuja atitude N25E/80SE é concordante à foliação $S n+1$. Os aplitos apresentam textura equigranular fina, geralmente. Possuem cores esbranquiçadas, são isótropos ou foliados e compostos por quartzo, plagioclásio e K-feldspato.

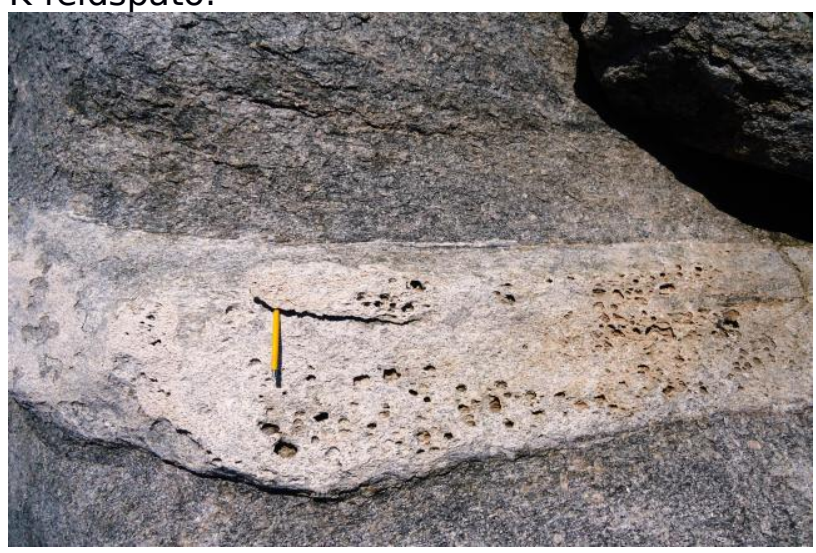

Figura 7 - Dique aplítico quartzo-feldspático com $70 \mathrm{~cm}$ de espessura, paralelo à foliação $\mathrm{Sn+1}$ do granito milonítico.

\subsection{Estruturas rúpteis}

Quando observadas das praias oceânicas de São Francisco deo Sul e do Balneário Barra do Sul, as llhas de Tamboretes chamam a atenção pela presença de feições pontiagudas verticalizadas. Estas feições resultam dos efeitos intempéricos ao longo de planos de fraturas, as quais são identificadas nas imagens de satélite do Google Earth (na escala 1:5.000) e confirmadas pelos dados de campo (Figura 8). Estas fraturas possuem três direções principais (E-W, NW-SE e NE-SW) são retilíneas ou levemente curvas e pode alcançar algumas dezenas de metros de comprimento. São raras as fraturas de direção NE-SW, subparalelas à foliação milonítica.

As famílias de fraturas presentes nas rochas possuem padrões e penetratividade variadas, espaçamento variando de $0,3 \mathrm{~cm}$ até 2 metros, geometria retilínea ou irregular (Figuras 2, 3 e 8) e têm distribuição heterogênea. Normalmente não estão preenchidas, porém de modo esparso ocorrem veios de quartzo. Não há indícios de deslocamentos ao longo de seus planos.

As fraturas escalonadas de atitude N60E/75SE, descritas no sudoeste da ilha do Norte e no norte da ilha do Sul têm comprimentos métricos (em torno de 1,5 m), espessura da ordem de $0,3 \mathrm{~cm}$ e são preenchidas por quartzo e epidoto. A disposição das fraturas sugere movimento sinistral.

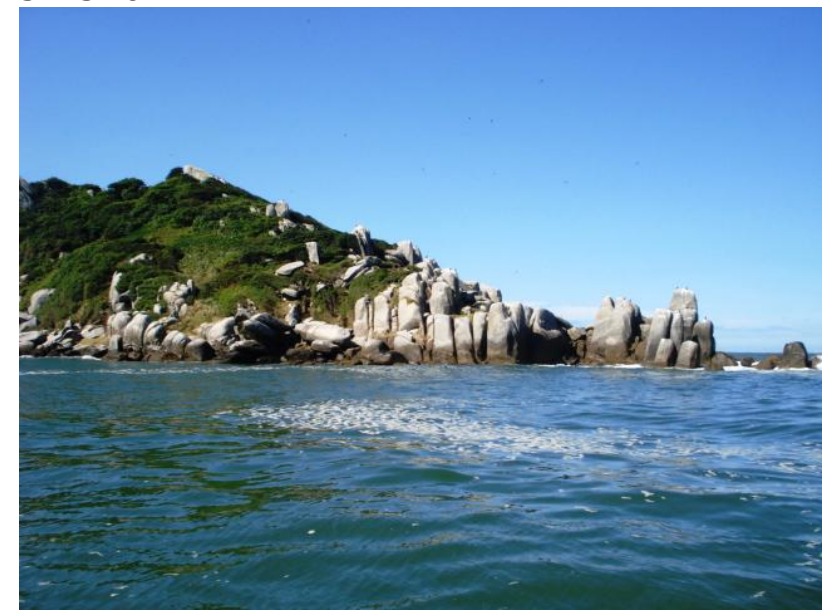

Figura 8 - Fraturas verticais em granitos foliados das ilhas de Tamboretes

As principais atitudes de fraturas são N85W/87NE, N85E/85SE, N80E/85NW e N75W/85SW.

Localmente ocorrem veios de quartzo de cor branca pouco fraturados, com aproximadamente $2 \mathrm{~cm}$ de espessura, no oeste da ilha do Norte, paralelos à foliação milonítica N15E/86NW. Veios de quartzo e epidoto em torno de $0,5 \mathrm{~cm}$ de espessura e veios quartzo-feldspáticos de 1 a $2 \mathrm{~cm}$ de largura também estão dispostos paralelamente à foliação.

\subsection{Geoquímica dos Granitos}

Três amostras de sienogranitos das ilhas de Tamboretes foram analisadas nos laboratórios da ACME (Tabela 1).

Os teores de $\mathrm{SiO} 2$ variam de $66,03 \%$ a $68,68 \%$ e possuem composição intermediária. Os valores de $\mathrm{Al} 2 \mathrm{O} 3$ e $\mathrm{Fe} 2 \mathrm{O} 3$ são relativamente elevados e as concentrações de $\mathrm{MgO}$ são um tanto baixas. Os teores de $\mathrm{Ba}$ e $\mathrm{Sr}$ são muito elevados, e os números de $\mathrm{Zr}, \mathrm{Nb}, \mathrm{Y}$ e ETR são consideravelmente baixos.

De acordo com a classificação de Frost et al. (2001), os granitos das ilhas de Tamboretes são álcali-cálcicos (Figura 9A). No diagrama $\mathrm{SiO} 2$ vs. FeOt/(FeOt+MgO) estas rochas se situam próximo da linha que divide os campos de assinatura ferrosa e magnesiana (Figura 9B).

Tabela 1 - Dados químicos dos sienogranitos das ilhas de Tamboretes. 


\begin{tabular}{|c|c|c|c|}
\hline & MTB - 33 & MTB - 26 & MTB - 31 \\
\hline $\mathrm{SiO}_{2}$ & 66,03 & 68,35 & 68,68 \\
\hline $\mathrm{TiO}_{2}$ & 0,42 & 0,31 & 0,36 \\
\hline $\mathrm{Al}_{2} \mathrm{O}_{3}$ & 15,74 & 15,52 & 14,82 \\
\hline $\mathrm{Fe}_{2} \mathrm{O}_{3}$ & 4,18 & 3,12 & 3,46 \\
\hline MnO & 0,10 & 0.07 & 0,08 \\
\hline MgO & 1,03 & 0,65 & 0,74 \\
\hline $\mathrm{Cr}_{2} \mathrm{O}_{3}$ & 0,006 & 0,007 & $<0,002$ \\
\hline CaO & 2,52 & 1,85 & 2,01 \\
\hline $\mathrm{Na}_{2} \mathrm{O}$ & 3,84 & 3,83 & 3,62 \\
\hline $\mathrm{K}_{2} \mathrm{O}$ & 4,83 & 5,13 & 4,51 \\
\hline $\mathbf{P}_{2} \mathrm{O}_{5}$ & 0,25 & 0,19 & 0,23 \\
\hline PF & 0,6 & 0,6 & 1,1 \\
\hline Total & 99,58 & 99,62 & 99,58 \\
\hline $\mathrm{Ba}$ & 1822 & 1769 & 1771 \\
\hline $\mathbf{R b}$ & 154,1 & 150,6 & 172,4 \\
\hline Sr & 950,6 & 830,7 & 896,8 \\
\hline $\mathrm{Zr}$ & 162,0 & 123,9 & 144,9 \\
\hline $\mathrm{Nb}$ & 14,3 & 13,9 & 19,7 \\
\hline $\mathbf{N i}$ & 43 & 50 & $<20$ \\
\hline Co & 5,0 & 4,4 & 4,8 \\
\hline Zn & 57 & 42 & 53 \\
\hline La & 40,1 & 28,8 & 34,8 \\
\hline $\mathrm{Ce}$ & 78,2 & 53,9 & 66,5 \\
\hline Pr & 8,58 & 5,92 & 8,35 \\
\hline Nd & 30,0 & 22,4 & 31,1 \\
\hline Sm & 5,46 & 4,00 & 5,23 \\
\hline Eu & 1,49 & 1,17 & 1,43 \\
\hline Gd & 3,79 & 2,90 & 4,40 \\
\hline Tb & 0,55 & 0,43 & 0,56 \\
\hline Dy & 2,86 & 2,81 & 2,58 \\
\hline Ho & 0,47 & 0,42 & 0,53 \\
\hline $\mathrm{Er}$ & 1,31 & 1,39 & 1,52 \\
\hline Tm & 0,22 & 0,23 & 0,25 \\
\hline Yb & 0,55 & 0,43 & 0,56 \\
\hline Lu & 0,25 & 0,23 & 0,25 \\
\hline $\mathbf{Y}$ & 16,0 & 13,7 & 16,9 \\
\hline Ta & 1,4 & 1,3 & 2,3 \\
\hline Hf & 4,8 & 3,9 & 3,9 \\
\hline Ga & 17,8 & 20,3 & 18,5 \\
\hline Sn & 2 & 2 & 6 \\
\hline Th & 11,6 & 11,7 & 10,5 \\
\hline $\mathbf{U}$ & 3,1 & 6,3 & 1,9 \\
\hline $\mathbf{A u}$ & 1,0 & 1,2 & 4,0 \\
\hline Mo & 5,8 & 6,3 & 1,3 \\
\hline $\mathrm{Cu}$ & 6,6 & 11,7 & 8,5 \\
\hline $\mathbf{N i}$ & 38,3 & 48,2 & 4,1 \\
\hline $\mathbf{P b}$ & 19,9 & 22,5 & 18,0 \\
\hline
\end{tabular}

No diagrama de índice de aluminosidade de Shand (Maniar e Piccoli 1989), os granitos das ilhas de Tamboretes são fracamente peraluminosos a ligeiramente metaluminosos (Figura 9C).

Quando normalizados pelo condrito de Nakamura (1974), os granitoides das ilhas de Tamboretes mostram moderado fracionamento de elementos terras raras (ETR) leves sobre os ETR's pesados (Figura 10). Os ETR's pesados possuem arranjo inclinado ou quase horizontal. As amostras têm altos valores de $\mathrm{Sr}$ sugerindo não ter havido retenção de plagioclásio na fonte, não exibem anomalia negativa de Eu e apresentam moderada depleção, indicando que a granada pode ter permanecido no resíduo ou participado do fracionamento, sugerindo maiores pressões (Rollinson 1993).
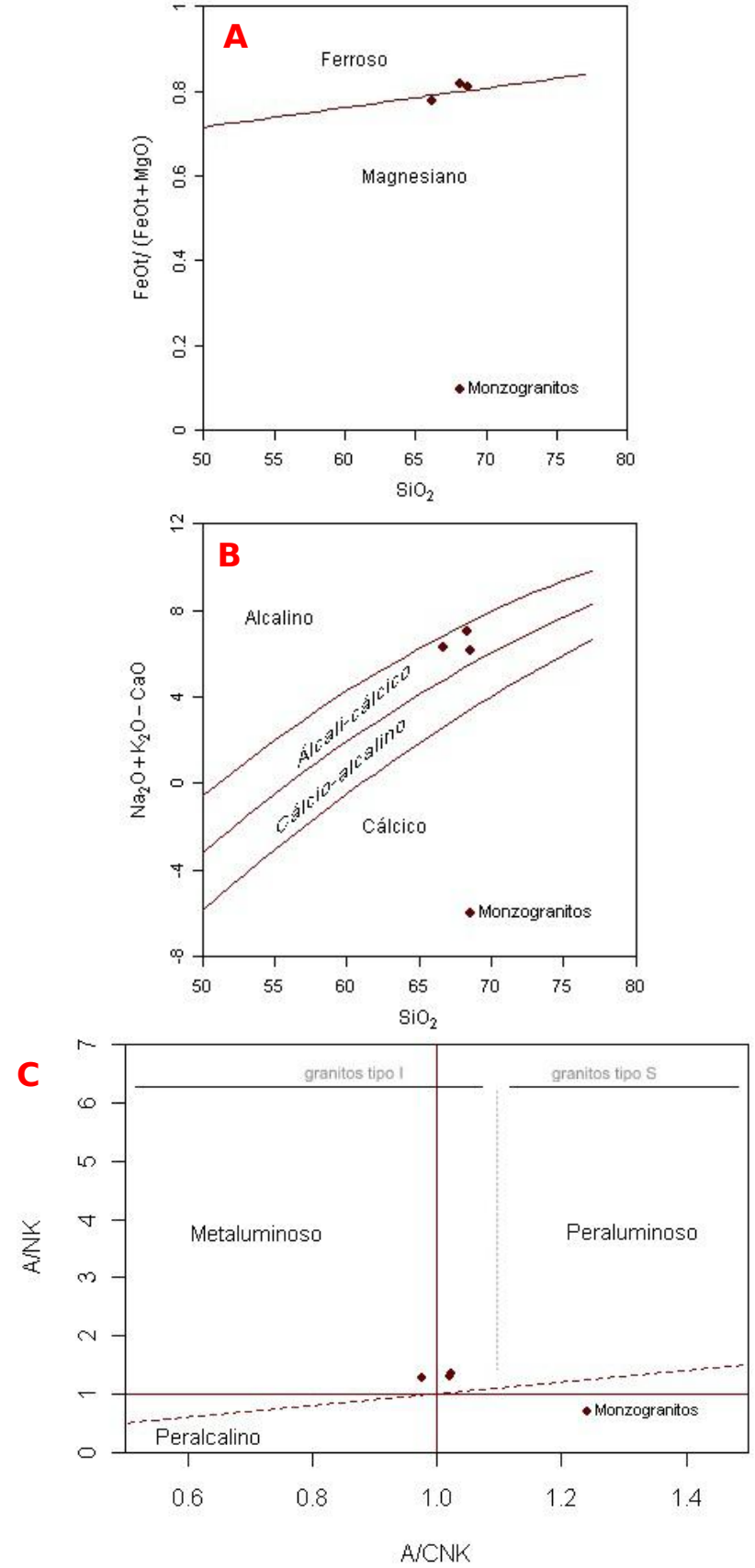

Figura 9 - Classificação de Frost et al. (2001) aplicado aos granitoides das ilhas de Tamboretes: A) $\mathrm{SiO} 2$ vs $\mathrm{Na} 2 \mathrm{O}+\mathrm{K} 2 \mathrm{O}-\mathrm{CaO}$; B) $\mathrm{SiO} 2$ vs $\mathrm{FeOt} /(\mathrm{FeOt}+\mathrm{MgO})$. C) Diagrama A/CNK vs A/NK de Maniar e Piccoli (1989) para os granitoides das ilhas de Tamboretes

Nos diagramas de discriminação de ambientes tectônicos propostos por Pearce et 
al. (1984), verifica-se que os granitos das ilhas de Tamboretes ocupam o campo de rochas de arco vulcânico (Figura 11A e 11B). Segundo o diagrama de Pearce (1996), os sienogranitos se situam no campo dos granitos pós-colisionais.
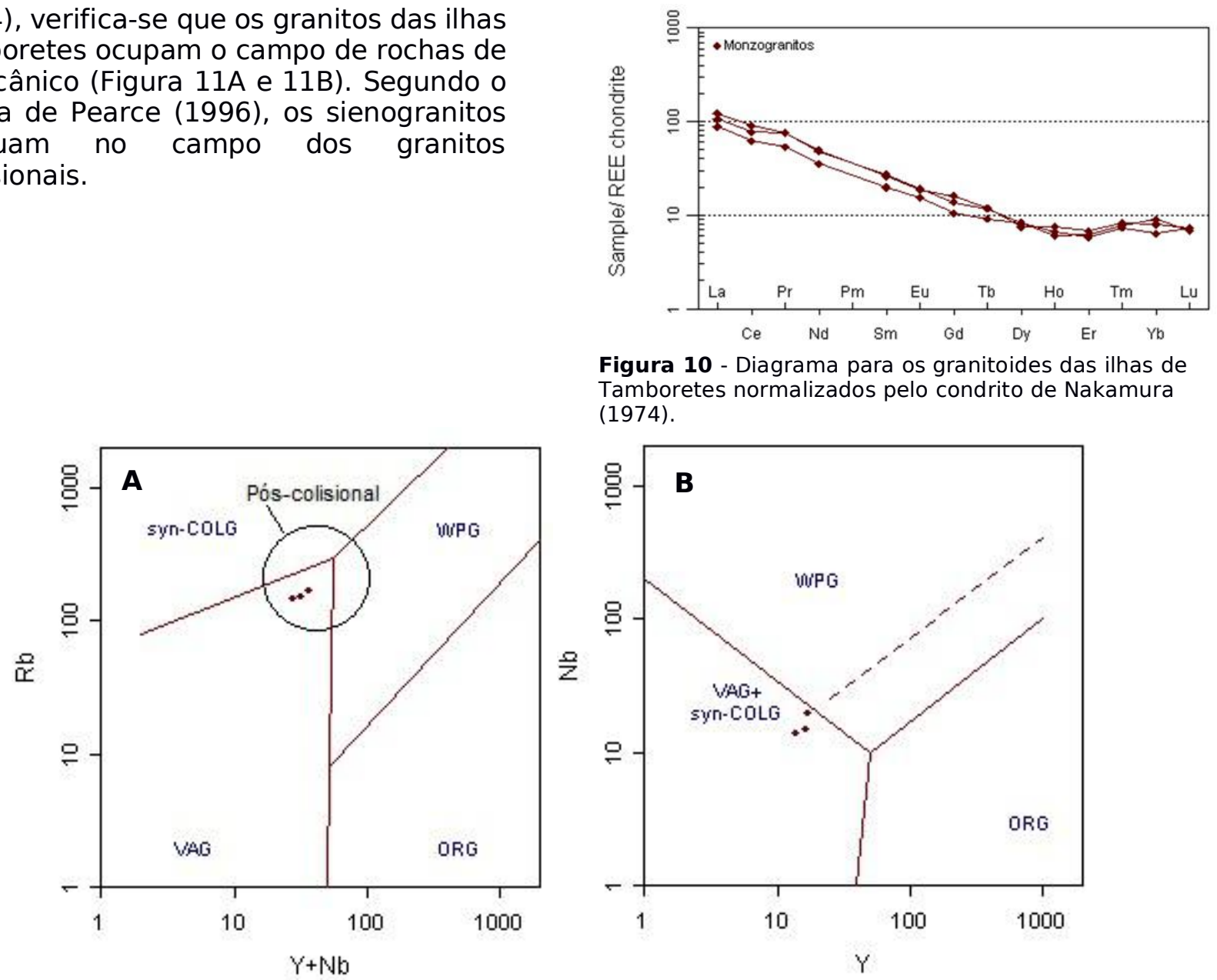

Figura 10 - Diagrama para os granitoides das ilhas de Tamboretes normalizados pelo condrito de Nakamura (1974).

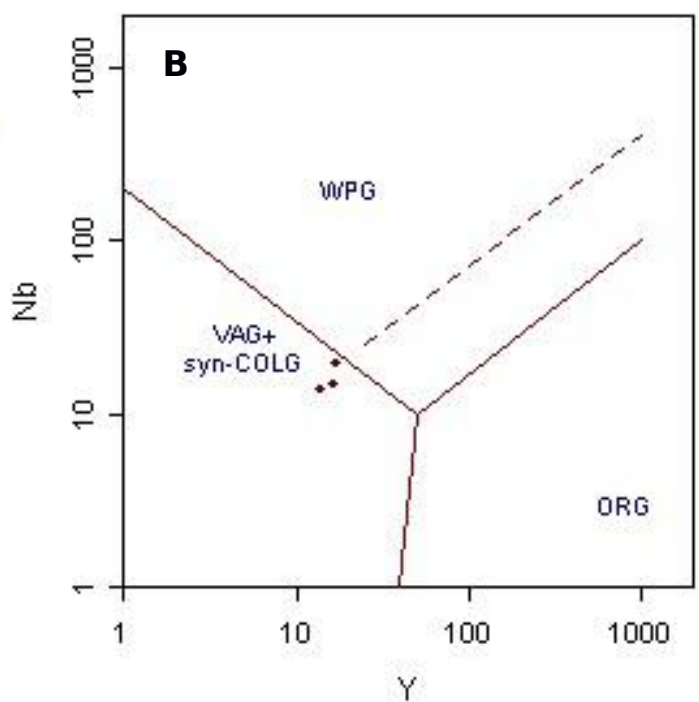

Figura 11 - Diagramas discriminantes de Pearce et al. (1984) e Pearce (1996) propostos para os granitos deformados das ilhas de Tamboretes. A) Diagrama $\mathrm{Y}+\mathrm{Nb}$ vs Rb. B) Diagrama $\mathrm{Y}$ vs Nb. Legenda: syn-COLG = granitos sin-colisionais; $\mathrm{VAG}=$ granitos de arco vulcânico; WPG = granitos intra-placa; ORG = granitos orogênicos.

\subsection{Diques de diabásio}

Localmente na parte oeste e sudoeste da Ilha do Norte, foram observados dois diques de diabásio, sendo um discordante em alto ângulo (Figura 12A) e o outro subparalelo da foliação milonítica (Figura 12B). O dique discordante em alto ângulo acompanha a direção das fraturas, possui direção N55W/70NE e tem espessura da ordem de 50 $\mathrm{cm}$. O dique concordante com a foliação milonítica é mais espesso, em torno de $1 \mathrm{~m}$, e apresenta direção preferencial N15E/88SE, subparalelo à foliação milonítica dos granitos.
Estes diabásios têm de cores cinza escuro, granulação fina e formados por augita $(\sim 50 \%)$, labradorita ( $50 \%)$, além de minerais acessórios (opacos e apatita) e de minerais de alteração (carbonato). O índice de cor é melanocrático e a estrutura é maciça.

Os cristais de augita são anédricos a subédricos prismáticos, finos a médios e não exibem orientação. Alguns cristais possuem as bordas e os centros corroídos.

Os cristais de labradorita são equigranulares finos, de hábito subédrico a euédrico ripiforme. Não apresentam orientação preferencial. Estão pouco sericitizados e moderadamente saussuritizados. 


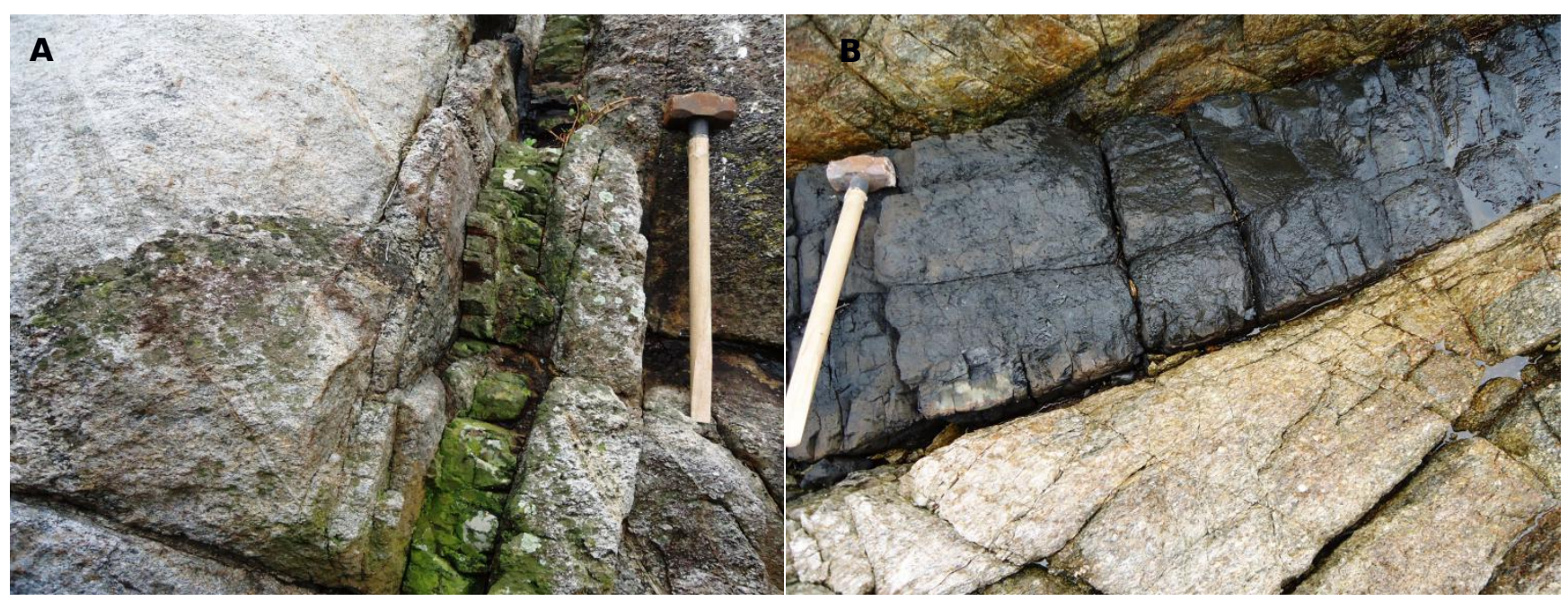

Figura 12 - (A) Dique de diabásio discordante e (B) concordante com a foliação milonítica.

\section{Conclusões}

As ilhas de Tamboretes são formadas por sienogranitos porfiríticos cálcio-alcalinos de alto $\mathrm{K}$ cujas características geoquímicas permitem compará-las aos granitos de arco magmático maduro (granitos do tipo I Cordilheirano), relacionados a ambientes compressivos. Várias suítes cálcio-alcalinas potássicas têm sido confundidas com sequências shoshoníticas, porque são também ricas em $\mathrm{Ba}$ e $\mathrm{Sr}$, com concentrações que são até superiores que as associações shoshoníticas (Morrison 1980). Conforme Brown et al. (1984) os granitoides de arco maduro exibem anomalias significativas de $\mathrm{Sr}$ e Ba. As concentrações elevadas de elementos LILE em relação a elementos HFSE são típicas de granitoides cálcio-alcalinos (Thompson et al. 1984). Magmas gerados em ambientes de margens destrutivas de placas são enriquecidos em elementos com baixo potencial iônico com relação aos elementos com alto potencial iônico (Hawkesworth e Voulmer 1979).

Os sienogranitos estudados apresentam concentrações elevadas de $\mathrm{Ba}$ e Sr. Moyen (2009) considera que as diferenças nos teores de $\mathrm{Sr}$ e $\mathrm{Y}$ podem sugerir diferenças na composição da fonte. Segundo Drummond e Defant (1990) também podem indicar diferenças na profundidade da fonte durante a geração de magmas. A presença de granada \pm hornblenda ou plagioclásio no resíduo ou entre as fases fracionadas é determinante para definir o campo de estabilidade de cada um deles (Moyen 2009).

As rochas das ilhas de Tamboretes mostram padrões moderadamente fracionados de ETR, além da ausência de anomalias negativas de Eu. Tais feições são atribuídas a magmas originados no campo de estabilidade da granada no resíduo em grandes profundidades e pressões (10-15 kbar), bem como a inexistência de plagioclásio na fase residual e fracionante, o que é compatível com os conteúdos elevados de Sr (Martin et al. 2005). A carência de uma anomalia de Eu também pode significar uma fugacidade de oxigênio muito alta, capaz de produzir concentrações altas de Ba e Sr.

Os sienogranitos estudados neste trabalho mostram semelhanças petrográficas, estruturais, geoquímicas com as rochas da Suíte Morro Inglês (Terreno Paranaguá), cuja idade de cristalização varia de 600 a $580 \mathrm{Ma}$ (Cury 2009).

Os granitos das ilhas de Tamboretes foram afetados por uma zona de cisalhamento transcorrente sinistral dúctil. A presença de novos grãos de feldspatos sugere temperaturas mínimas próximas de $450^{\circ} \mathrm{C}$. A direção N15-25E desta zona de cisalhamento se aproxima das direções de outras importantes zonas de cisalhamento transcorrente do estado de Santa Catarina, a exemplo das falhas Major Gercino, Itajaí-Mirim, e Itajaí-Perimbó.

Os diques de diabásio observados na ilha do Norte (Arquipélago de Tamboretes) possuem 
direção preferencial NW e NE. O dique de orientação NW-SE possivelmente se relaciona com os enxames de diques mesozoicos do Arco de Ponta Grossa. O dique de direção NE-SW é concordante à foliação $S n+1$, sugerindo que a influência de anisotropias estruturais na colocação destes diques.

\section{Agradecimentos}

Os autores agradecem o apoio institucional da Universidade Federal do Paraná, do Departamento de Geologia e ao Programa de pós-graduação em Geologia da UFPR. M.T. Baldin agradece à Capes pela bolsa de mestrado. C.E.M. Barros agradece ao Conselho de Desenvolvimento Científico Nacional - CNPq pela bolsa de produtividade em pesquisa (Grants 306.021/2012-9 e 309.625/2015-7). Os autores agradecem aos editores pela oportunidade e aos revisores pelas valiosas contribuições. Somos gratos à Sra. Anice Ambrósio de Mesquita Barros pela hospedagem no Balneário de Barra do Sul durante os trabalhos de campo.

\section{Referências bibliográficas}

BASEI M.A.S. 1985. O Cinturão Dom Feliciano em Santa Catarina. Tese de Doutorado. Instituto de Geociências, Universidade de São Paulo, São Paulo, $190 \mathrm{f}$.

BASEI M.A.S., MCREATH I., SIGA JUNIOR O. 1998. The Santa Catarina Granulite Complex of southern Brazil, a review. Gondwana Research, 1: 383-391.

BASEI M.A.S., SIGA JÚNIOR O., MACHIAVELLI A., MANCINI F. 1992. Evolução tectônica dos terrenos entre os Cinturões Ribeira e Dom Feliciano (PR - SC). Revista Brasileira de Geociências. 22(2): 216-221.

BASEI M.A.S., SIGA JUNIOR O., REIS NETO J.M. 1990. O Batólito Paranaguá. Proposição, idade, considerações petrogenéticas e implicações tectônicas. In: Congresso Brasileiro de Geologia, 36, Natal. Anais. SBG, 4: 1684-1699.

BASEI M.A.S., TEIXEIRA W. 1987. Geocronologia dos terrenos Pré-Cambrianos a Eo-Paleozóicos de Santa Catarina. In: SILVA L.A., BERTOLUZZI C.A. Texto explicativo para o mapa geológico do Estado de Santa Catarina - 1:500.000. Florianópolis, DNPM/CPRM.

BROWN G.C., THORPE R.S., WEBB P.C. 1984. The geochemical characteristics of granitoids in contrasting arcs and comments on magma sources. Journal of Geological Society London, 141: 413-426.

Cury L.F. 2009. Geologia do Terreno Paranaguá. Tese de Doutorado. Instituto de Geociências, Universidade de São Paulo, 202 p.

DNPM - DEPARTAMENTO NACIONAL DA PRODUÇÃO MINERAL 1986. Mapa geológico do Estado de Santa Catarina. Florianópolis, escala 1:500.000.

DRUMMOND M. S., DEFANT M. J. 1990. A model for Trondhjemite-Tonalite-Dacite Genesis and crustal growth via slab melting: archaean to modern comparisons. Journal of Geophysical Research 95: 21503-21521.

FIGUEIREDO M.C.H., BASEI M.A.S., MANTOVANI M.S.M., FRYER B.J. 1991. O Complexo Granulítico de Santa Catarina: um arco insular arqueano? Boletim IG-USP, Publicação Especial, 9: 35-40.

FIGUEIREDO M.C.H., MCREATH I., BASEI M.A.S., MANTOVANI M.S.M. 1997. Geochemistry of part of the Santa Catrina Granulitic Complex, southern Brazil: A model of differentiation from high alumina basalts. Revista Brasileira de Geociências, São Paulo, 27: 33-40.

FROST B.R., BARNES C.G., COLLINS W.J., ARCULUS R.J., ELLIS D.J., FROST C.D. 2001. A geochemical classification for granitic rocks. Journal of Petrology, 42 (11): 2033-2048.

HARARA O.M.M., BASEI M.A.S., SIGA JUNIOR O. 2001. First evidence for expressive neoproterozoic intraplated mafic rocks and magma mixing in post-collision A-PA type granites southern Brazil: Geochemestry an U-Pb (zircon), Nd-Sr-O (zircon) isotope investigations: In: III SSAGI, Pucon - Chile, CD-ROM.

HARTMANN L.A. 1976. Ocorrência de granulitos em Luís Alves, SC. In: Congresso Brasileiro de Geologia, Belo Horizonte. Boletim de Resumos. Belo horizonte, SBG, 29: 321.

HARTMANN L.A., SANTOS J.O.S., MCNAUGHTON N.J., VASCONCELLOS M.A.Z., SILVA L.C. 2000. Íon microporbe (SHRIMP) dates complex granulite from Santa Catarina, southern Brazil. Anais da Academia Brasileira de Ciência, 72 (4): 560-572.

HARTMANN L.A., SILVA L.C., ORLANDI FILHO, V. 1979. O Complexo Granulítico de Santa Catarina. Descrição e implicações genéticas. Acta Geológica Leopoldensia, 3: 93-112.

HASUI Y., CARNEIRO C.D.R., COIMBRA A.M. 1975. The Ribeira Folded Belt. Revista Brasileira de Geociências, 5: 257-266.

HAWKESWORTH C. J., VOULMER R. 1979. Crustal contamination versus enriched mantle: $143 \mathrm{Nd} / 144 \mathrm{Nd}$ and $87 \mathrm{Sr} / 86 \mathrm{Sr}$ evidence from the Italian volcanics. Cont. Mineral petrol. 69: 151-165.

IGLESIAS C.M.F., ZERFASS H., SILVA M.A.S., KLEIN C. 2011. Mapa Geológico da Folha Joinville - SG.22-Z-B. Brasília, CPRM, escala 1:250.000.

IBGE - INSTITUTO BRASILEIRO DE GEOGRAFIA E ESTATÍSTICA 1981. Folha Topográfica de Araquari SG-22-Z-B-II-4/MI-2870-4. Rio de Janeiro, escala 1:50.000.

IBGE - INSTITUTO BRASILEIRO DE GEOGRAFIA E ESTATÍSTICA 2004. Folha de Joinville SG.22-Z-B/MIR-519. Rio de Janeiro, escala 1:250.000.

KAUL P.F.T. 1979. Pré-Cambriano e Eopaleozóico do nordeste de Santa Catarina e leste do Paraná: Reavaliação de dados e correlações com a África. In: Simpósio regional de Geologia, Rio Claro. Atas. Rio Claro, SBG, 1: 1-15.

KAUL P.F.T. 1980. O Cráton de Luís Alves. In: Congresso Brasileiro de Geologia, 31, Camboriú. Anais. Camboriú, SBG, 5: 2677-2683.

KAUL P.F.T., TEIXEIRA W. 1982. Archean and early Proterozoic complexes of Santa Catarina, Paraná and São Paulo states, south-southeaster, Brazil: an outline 
Baldin \& Barros/Boletim Paranaense de Geociências 73-1 (2017) 01 - 14

of their geological evolution. Revista Brasileira de Geociências, 12(1/3): 172-182.

LOPES O.F. 1987. O granito sin-tectônico Cubatãozinho: petrogênese e evolução geológica. In: SIMPÓSIO SUL BRASILEIRO DE GEOLOGIA, 3, Curitiba. Atas. Curitiba, SBG, 2: 481-490.

MACHIAVELLI A., BASEI M.A.S., SIGA JUNIOR O. 1993. Suíte Granítica Rio Piên: um arco magmático do Proterozóico Superior na microplaca Curitiba. Geochimica Brasiliensis, Rio de Janeiro, 7(2): 113-129.

MANIAR P.D., PICCOLI P.M. 1989. Tectonic discrimination of granitoids. Geological Society of America, Bulletin, 101, 5: 635-643.

MANTOVANI M.S.M., SHUKOWSKY W., BASEI M.A.S., VASCONCELOS A.C.B.C. 1989. Modelo gravimétrico das principais descontinuidades crustais nos terrenos Pré-Cambrianos dos Estados do Paraná e Santa Catarina. Revista Brasileira de Geociências, 19(3): 367-374.

MARTIN H., SMITHIES R. H., RAPP R., MOYEN J.F., CHAMPION D. 2005. An overview of adakite, tonalite-trondhjemitegranodiorite (TTG), and sanukitoid: relationships and some implications for crustal evolution. Lithos 79(1-2): 1-24.

MORRISON G. W. 1980. Characteristics and tectonic setting of the shoshonite rock association. Lithos, 13: 97-108.

MOYEN J. F. 2009. High Sr/Y and La/Yb ratios: the meaning of the "adakitic signature". Lithos 112(3-4): 556-574.

NAKAMURA N. 1974. Determination of REE, Ba, Fe, Mg, Na and $\mathrm{K}$ in carbonaceous and ordinary chondrites. Geochimica et Cosmochimica Acta, 38: 757-775.

PEARCE J.A. 1996. Source and settings of granitic rocks. Episodes, 19: 120-125.

PEARCE J.A., HARRIS N.B.W., TINDLE A.G. 1984. Trace element discrimination diagrams for the tectonic interpretation of granitic rocks. Journal of Petrology, 4: 956-983.

ROLLINSON H. 1993. Using geochemical data: evaluation, presentation, interpretation. Grã Bretanha: Longman Group UK Ltd, 352 p.

SIBSON R.H. 1977. Fault rocks and fault mechanisms. Journal of Geological Society of London, 133: 191-213.

SATO K., SIGA JUNIOR O., NUTMAN A.P., BASEI M.A.S., MC REATH I., KAULFUSS G.A. 2003. The Atuba Complex, Southern South American Plataform: Archean components and Paleoproterozoic to Neoproterozoic tectonothermal events. Gondwana Research, 6 (2): 251-263.

SIGA JUNIOR. 1995. Domínios tectônicos do sudeste do Paraná e nordeste de Santa Catarina: Geocronologia e evolução Crustal. Tese de Doutorado, Instituto de Geociências, USP, 212 p.

SIGA JUNIOR O., BASEI M.A.S., MACHIAVELLI A. 1990. Evolução geotectônica do Maciço de Joinville, PR e SC. Jornadas Científicas do Instituto de Geociências, USP, Boletim especial, 116-118.

SIGA JUNIOR O., BASEI M.A.S., MACHIAVELLI A. 1993. Evolução geotectônica da porção NE de Santa Catarina e SE do Paraná, com base em interpretações geocronológicas. Revista Brasileira de Geociências, 23:(3) 215-223.

SIGA JUNIOR O., BASEI M. A. S., PASSARELLI C. R., HARARA O. M., SATO K., CURY L. F., PRAZERES FILHO H. J. 2007. Geocronologia de rochas gnáissico-migmatíticas e sienograníticas do Núcleo Setuva (PR): implicações tectônicas. Revista Brasileira de Geociências, 37: 114-128.

SILVA L.C. 1984. Os terrenos de médio a alto grau do Pré-Cambriano de Santa Catarina. Congresso Brasileiro de Geologia, 33, Rio de Janeiro. Anais, Rio de Janeiro, SBG, 3: 3069-3080.

SILVA L.C. 1987. Geologia do Pré-Cambriano Eopaleozóico de Santa Catarina. In: SILVA, L.C., BORTOLUZZI C.A. Texto explicativo para o mapa geológico do Estado de SC. Florianópolis, DNPM/CPRM, 12-90.

THOMPSON R.N., MORRISON M.A., HENDRY G.L., PARRY S.J. 1984. An assessment of the relative roles of crust and mantle in magma genesis: an elemental approach. Philosophical Transactions of the Royal Society of London. Serie A, 310: 549-590.
Manuscrito ID 38498

Submetido em outubro de 2014 Aceito em fevereiro de 2017 